\title{
Postnatal expression pattern of the C/EBP alpha gene in porcine subcutaneous adipose tissue
}

\author{
J.F. Jiang, Z.R. Xu' ${ }^{1}$, Y.Z. Wang, X.Y. Han and L.Wang \\ Feed Science Institute, Zhejiang University \\ Qiutao North Road 164, Hangzhou, 310029, China
}

(Received 1 August 2005; revised version 9 November 2005; accepted 6 January 2006)

\begin{abstract}
CCAAT/enhancer binding protein $\alpha(\mathrm{C} / \mathrm{EBP} \alpha)$ has been implicated as a key regulator of adipocyte differentiation and lipid metabolism. The pattern of $\mathrm{C} / \mathrm{EBP} \alpha$ gene expression in different growth stages and its relation to adipose deposition was studied. Fifteen female Duroc $\times$ Landrace $\times$ Yorkshire pigs in five groups of three pigs each, weighing 1,30,50, 70 and $90 \mathrm{~kg}$ were used to study developmental gene expression of $\mathrm{C} / \mathrm{EBP} \alpha$ in subcutaneous adipose tissue by means of semi-quantitative RT-PCR. The results showed that the C/EBP $\alpha$ mRNA levels in porcine adipose tissue continuously increased as the pigs grew and deposited fat from 1 to $90 \mathrm{~kg}$ body weight $(\mathrm{BW})$ $(\mathrm{P}<0.05)$. The presented data show a close positive correlation between the levels of $\mathrm{C} / \mathrm{EBP} \alpha$ gene expression and the fat deposition rate in pigs. The experiment showed that total adipose weight increased significantly with $\mathrm{BW}(\mathrm{P}<0.05)$.
\end{abstract}

KEY WORDS: $\mathrm{C} / \mathrm{EBP} \alpha$, transcription factor, gene expression, fat deposition, pigs

\section{INTRODUCTION}

CCAAT/enhancer binding protein $\alpha$ (C/EBP $\alpha$ ) belongs to the bZIP protein family of nuclear transcription factors, which contain a basic region and a leucine zipper domain in the C-terminal part of the molecule (Vinson et al., 1989). This transcription factor is expressed at high levels in quiescent hepatocytes and in differentiated adipocytes (Umek et al., 1991).

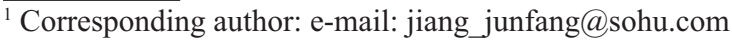


The key role of $\mathrm{C} / \mathrm{EBP} \alpha$ in adipocyte differentiation is now well established (MacDougald and Lane, 1995). Many adipocyte-expressed genes possess C/EBP binding sites in their proximal promoters that mediate transactivation by $\mathrm{C} / \mathrm{EBP} \alpha$. Compelling evidence shows that $\mathrm{C} / \mathrm{EBP} \alpha$ is required for adipocyte differentiation. Expression of $\mathrm{C} / \mathrm{EBP} \alpha$ under control of an inducible promoter is sufficient to induce adipocyte differentiation of 3T3-L1 preadipocytes in the absence of exogenous hormonal stimuli. Conversely, expression of antisense C/EBP $\alpha$ RNA in 3T3-L1 preadipocytes blocks the normal differentiation program, and transfection of a "sense" C/EBP $\alpha$ RNA expression vector into the "anti-sense" cells restores their capacity to differentiate (Lin and Lane, 1992). These findings are supported by investigations with $\mathrm{C} / \mathrm{EBP} \alpha$ knock-out mice, which fail to develop adipose tissue normally or to accumulate triglycerides, the hallmark of white adipose tissue (Wang et al., 1995).

Efficient production of good quality pig meat may be obtained by reducing the total fat amounts while fat depots important for meat quality are kept at optimum levels. The aim of this experiment was to determine the pattern of $\mathrm{C} / \mathrm{EBP} \alpha$ gene expression in different growth stages and its relation to adipose deposition to obtain information for regulating meat production quality.

\section{MATERIAL AND METHODS}

\section{Animals}

A total of fifteen female Duroc $\times$ Landrace $\times$ Yorkshire pigs in five groups, each group containing three pigs weighing $1,30,50,70$, or $90 \mathrm{~kg}$ (three replicates for each age group) were euthanized under anaesthesia and exsanguinated after a $12 \mathrm{~h}$ fast and ad libitum access to water. Subcutaneous adipose tissue was quickly dissected and frozen in liquid nitrogen, then stored at $-70^{\circ} \mathrm{C}$ until extraction of total RNA. Left-half carcasses were weighed after the head, hooves, tail, viscera (except the kidney) were removed, subcutaneous, ventral and mesentery adipose tissues in left-half carcasses were dissected and weighed, and fat deposition rates, calculated. All of the animal experiments were done according to the guidelines for animal experiments at the National Institute of Animal Health.

\section{Extraction of RNA}

The following materials were used: mortars and pestles (baked overnight at $180^{\circ} \mathrm{C}$ ), pipette tips (DEPC-treated and autoclaved), gel running apparatus (treated with 3\% $\mathrm{H}_{2} \mathrm{O}_{2}$ and incubated overnight with DEPC-treated water), $1.5 \mathrm{ml}$ polypropylene 
centrifuge tubes (washed and incubated overnight at room temperature with DEPC-treated water).

The RNA extraction procedure was as follows:

1. Using a mortar and pestle, $100 \mathrm{mg}$ of adipose tissue were ground to a fine powder, while continuously adding liquid nitrogen to the mortar to keep the sample frozen.

2. The tissue powder was rapidly transferred to a centrifuge tube and $1 \mathrm{ml}$ TRIzol Reagent (Sigma, USA) was added and then mixed until thoroughly suspended (a turbid solution was formed).

3. Centrifugation at $12,000 \times \mathrm{g}$ at $4^{\circ} \mathrm{C}$ for $10 \mathrm{~min}$ and removal of the fatty layer on the surface of the aqueous phase.

4. The aqueous layer was transferred to a fresh centrifuge tube, $200 \mu 1$ chloroform was added and mixed for $30 \mathrm{sec}$.

5. Centrifugation at $12,000 \times \mathrm{g}$ at $4^{\circ} \mathrm{C}$ for $10 \mathrm{~min}$, and the upper clear phase was carefully transferred to a fresh centrifuge tube.

6. An equal volume of isopropanol was added and mixed, allowing the sample to stand for $10 \mathrm{~min}$ at room temperature, and then centrifuged for $10 \mathrm{~min}$ at $12,000 \times \mathrm{g}$ at $4^{\circ} \mathrm{C}$.

7. The supernatant was removed and the RNA pellet washed by adding $0.75 \mathrm{ml}$ of $75 \%$ chilled ethanol, and then centrifuged at $12,000 \times \mathrm{g}$ at $4^{\circ} \mathrm{C}$ for $5 \mathrm{~min}$.

8. The RNA pellet was dried at room temperature and dissolved in DEPC-treated autoclaved water.

9. The RNA was quantified by measuring the absorbance at $260 \mathrm{~nm}$. The A260/280 ratio was also calculated.

Synthesis of cDNA

Synthesis of first-strand cDNA was performed using a Reverse Transcription System kit (first-strand cDNA-synthesis kit, Promega, USA) as described by the manufacturer with oligodT-primer and using approximately $1 \mu \mathrm{g}$ of total RNA treated with DNase as the template.

$P C R$

The reverse-transcribed cDNA was amplified with Taq DNA polymerase (Promega, USA) by polymerase chain reaction (PCR) in a thermocycler (Gene Amp PCR system 9600) using paired sense and antisense primers designed by the Primer Premier 5.0 software (Table 1). Primer sequences for the C/EBP $\alpha$ gene were designed based on known sequences (Antonson and Xanthopoulos, 1995) and part of a single exon was amplified. The primers were synthesized by Shanghai Sangon Biological Engineering Technology and Services Co., Ltd (China). The conditions for PCR for 
Table 1. Primers sequences for $\mathrm{C} / \mathrm{EBP} \alpha$ and $\beta$-actin genes

\begin{tabular}{clcc}
\hline Gene & \multicolumn{1}{c}{ Primers } & Size (bp) & Species \\
\hline C/EBP $\alpha$ & S: 5'-GGTGGACAAGAACAGCAACG -3' & 370 & porcine \\
& A: 5'-AGGCACCGGAATCTCCTAGT -3' & & \\
\hline \multirow{3}{*}{-actin } & S: 5'-GGAGATCGTGCGGGACAT-3' & 318 & porcine \\
& A: 5'-GTTGAAGGTGGTCTCGTGGAT-3' & & \\
\hline
\end{tabular}

$\mathrm{C} / \mathrm{EBP} \alpha$ were: denaturation at $94^{\circ} \mathrm{C}$ for $2 \mathrm{~min}$, followed by 31 cycles of amplification at $94^{\circ} \mathrm{C}$ for $50 \mathrm{~s}, 56^{\circ} \mathrm{C}$ for $50 \mathrm{~s}$, and $72^{\circ} \mathrm{C}$ for $1 \mathrm{~min}$, and followed by final extension at $72^{\circ} \mathrm{C}$ for $10 \mathrm{~min}$. The conditions for PCR for $\beta$-actin were: denaturation at $94^{\circ} \mathrm{C}$ for $2 \mathrm{~min}$, followed by 31 cycles of amplification at $94^{\circ} \mathrm{C}$ for $50 \mathrm{~s}, 53^{\circ} \mathrm{C}$ for $50 \mathrm{~s}$, and $72^{\circ} \mathrm{C}$ for $1 \mathrm{~min}$, and followed by final extension at $72^{\circ} \mathrm{C}$ for $10 \mathrm{~min}$.

DNA sequencing and sequence analysis

DNA sequencing and sequence analysis were performed by the method described by Khoo et al. (2003).

$m R N A$ expression analysis

The expression of pig C/EBP $\alpha$ gene mRNAwas determined by semi quantitative RT-PCR (Tengku Muhammad et al., 2000) using the housekeeping beta-actin gene as an external control. The PCR products were electrophoresed on $1 \%(\mathrm{w} / \mathrm{v})$ agarose gel, electrophoresis band intensities of the PCR products were quantified using NIH Image Version 1.62 software.

Statistical analysis

All the data were analysed statistically according to the ANOVA procedure (SAS Institute, 1989) and the treatment means were separated by Duncan's multiple range test. Statistical significance was at $\mathrm{P}<0.05$ for all statistical tests.

\section{RESULTS}

\section{Developmental pattern of $C / E B P \alpha$ gene expression}

The developmental pattern of $\mathrm{C} / \mathrm{EBP} \alpha$ gene expression of adipose tissue in pigs with liveweight of 1, 30, 50, 70 and 90 was evaluated using semi-quantitative RT-PCR, which allows the assessment of relative $\mathrm{C} / \mathrm{EBP} \alpha$ mRNA levels in pigs at different growth stages. The results of electrophoresis of PCR products of three 


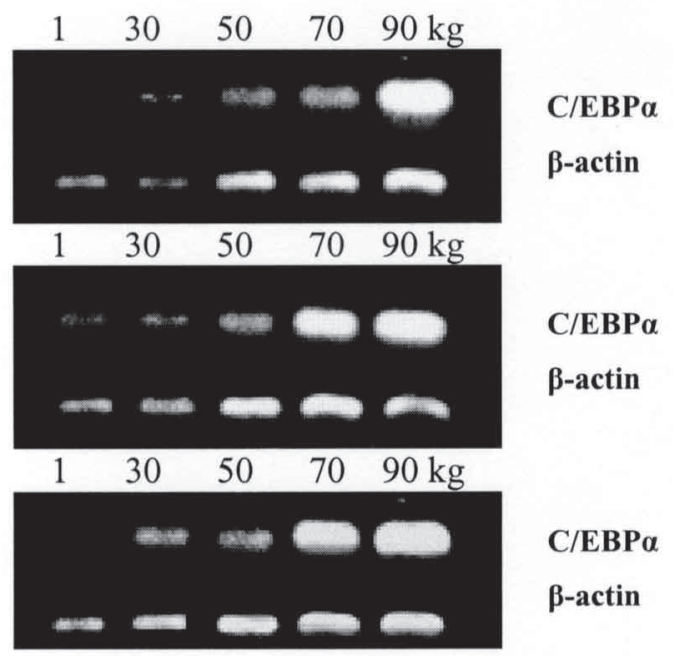

Figure 1. Electrophoresis of RT-PCR products for $\mathrm{C} / \mathrm{EBP} \alpha$ and $\beta$-actin genes in the subcutaneous adipose tissue of pigs weighed 1,30,50, 70 and $90 \mathrm{~kg}$. (1), (2), (3): the products from the first pig, the second pig and the third pig in each weight group, respectively

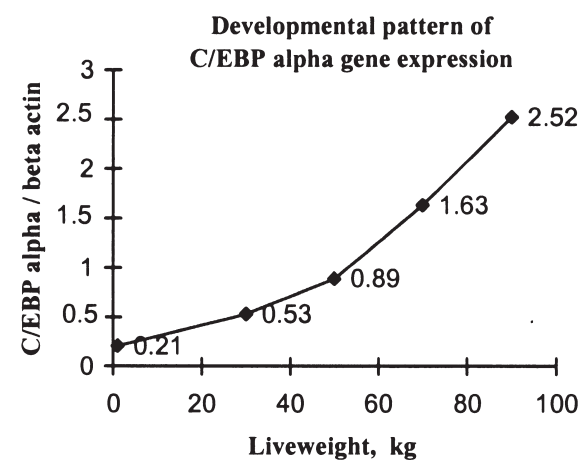

Figure 2. The pattern of $\mathrm{C} / \mathrm{EBP} \alpha \mathrm{mRNA}$ levels in the subcutaneous adipose tissue of pigs weighed 1 , $30,50,70$ and $90 \mathrm{~kg}$. The data show the mean mRNA level of three pigs in each weight group as the ratio of the band intensity of each PCR product to the corresponding $\beta$-actin PCR product

pigs from each group are shown in Figure 1, C/EBP $\alpha$ gene mRNA was detected in pig adipose tissue at all stages of growth. As shown in Figure 2, the C/EBP $\alpha$ gene expression in porcine adipose tissue was weight-dependent. C/EBP $\alpha$ mRNA was present in a very low concentration at birth (the relative quantity was 0.21 ). The relative $\mathrm{C} / \mathrm{EBP} \alpha \mathrm{mRNA}$ levels $(\mathrm{C} / \mathrm{EBP} \alpha / \beta$-actin) steadily increased from $0.21,0.53,0.89,1.63$, to 2.52 as the pigs grew $(\mathrm{P}<0.05)$, the highest expression of $\mathrm{C} / \mathrm{EBP} \alpha$ mRNA was observed at the highest, $90 \mathrm{~kg}$, body weight. 


\section{Developmental pattern of fat deposition}

Table 2 shows that the fat (subcutaneous, ventral and mesentery adipose tissues) deposition rates were $7.94,11.48,14.99,16.75$, and $20.73 \%$ at the growth stages of $1,30,50,70$, and $90 \mathrm{~kg}$ liveweight, respectively, of pigs. The ratio increased significantly at all stages studied $(\mathrm{P}<0.01)$. The weight of the subcutaneous, ventral and mesenteric adipose tissues at different growth stages increased significantly between all stages studied $(\mathrm{P}<0.01)$, with the subcutaneous adipose tissue accounting for the highest percentage (Table 2).

Table 2 . Developmental adipose deposition (mean \pm SD)

\begin{tabular}{ccccc}
\hline $\begin{array}{c}\text { Liveweight } \\
\mathrm{kg}\end{array}$ & $\begin{array}{c}\text { Subcutaneous } \\
\text { adipose } \\
\mathrm{kg}\end{array}$ & $\begin{array}{c}\text { Ventral adipose } \\
\mathrm{kg}\end{array}$ & $\begin{array}{c}\text { Mesenteric } \\
\text { adipose } \\
\mathrm{kg}\end{array}$ & $\begin{array}{c}\text { Fat deposition } \\
\text { rate } \\
\%\end{array}$ \\
\hline 1 & $0.031^{\mathrm{a}} \pm 0.017$ & $0.003^{\mathrm{a}} \pm 0.001$ & $0.028^{\mathrm{a}} \pm 0.002$ & $7.94^{\mathrm{a}} \pm 0.75$ \\
30 & $1.236^{\mathrm{b}} \pm 0.036$ & $0.042^{\mathrm{a}} \pm 0.002$ & $0.395^{\mathrm{b}} \pm 0.043$ & $11.48^{\mathrm{b}} \pm 0.23$ \\
50 & $3.890^{\mathrm{c}} \pm 0.053$ & $0.254^{\mathrm{b}} \pm 0.124$ & $0.605^{\mathrm{c}} \pm 0.099$ & $14.99^{\mathrm{c}} \pm 0.43$ \\
70 & $6.661^{\mathrm{d}} \pm 0.536$ & $0.344^{\mathrm{c}} \pm 0.068$ & $1.029^{\mathrm{d}} \pm 0.059$ & $16.75^{\mathrm{d}} \pm 1.13$ \\
90 & $11.12^{\mathrm{e}} \pm 0.308$ & $0.920^{\mathrm{c}} \pm 0.076$ & $1.798^{\mathrm{e}} \pm 0.226$ & $20.72^{\mathrm{e}} \pm 0.57$ \\
\hline
\end{tabular}

means within a column with different superscripts are significantly different $(\mathrm{P}<0.05)$

The relation between $C / E B P \alpha$ gene expression and fat deposition

$\mathrm{C} / \mathrm{EBP} \alpha$ mRNA levels increased as fat was deposited from 1 to $90 \mathrm{~kg}$ body weight (Figures 2 and 3; $\mathrm{P}<0.05$ ). Correlation analysis showed that there was a positive correlation between the levels of $\mathrm{C} / \mathrm{EBP} \alpha$ gene expression and the fat deposition rate $(\mathrm{r}=0.87, \mathrm{P}<0.05)$ during growth from 1 to $90 \mathrm{~kg}$ body weight.

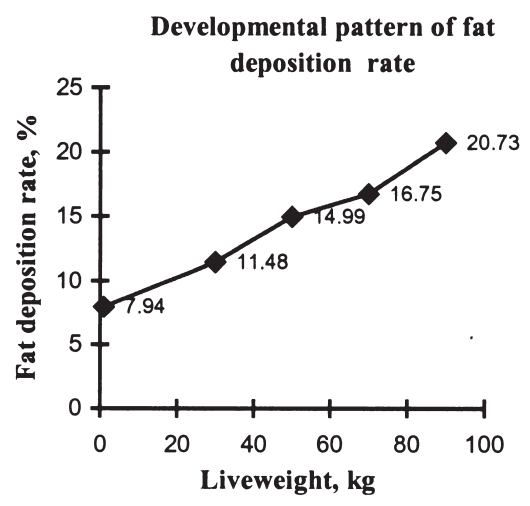

Figure 3. The pattern of fat deposition rate in pigs weighed 1, 30, 50, 70 and $90 \mathrm{~kg}$. The data show the mean of fat deposition rate of three pigs in each weight group 


\section{DISCUSSION}

\section{Developmental pattern of adipocyte C/EPB $\alpha$ gene expression}

This study showed that $\mathrm{C} / \mathrm{EBP} \alpha \mathrm{mRNA}$ was present at birth at a very low concentration (only $0.84 \%$ of that at the stage of $90 \mathrm{~kg}$ liveweight) and that the relative quantity of $\mathrm{C} / \mathrm{EBP} \alpha \mathrm{mRNA}(\mathrm{C} / \mathrm{EBP} \alpha / \beta$-actin) steadily increased as pigs grew. Ding (1999) also found that porcine $\mathrm{C} / \mathrm{EBP} \alpha$ transcripts were at a continuously low concentration in adipose tissue until a several-fold increase occurred between 17 and 28 days postpartum. Lee et al. (1998) detected the $\mathrm{C} / \mathrm{EBP} \alpha$ protein in foetal pigs at 50 days postconception in the nuclei of cells located in the region of development of porcine subcutaneous adipose tissue. By days 75 and 95 post-conception, there are differentiated fat cells that have nuclei positive for the $\mathrm{C} / \mathrm{EBP} \alpha$ protein. The detection of the $\mathrm{C} / \mathrm{EBP} \alpha$ protein in the nuclei of partially differentiated adipocytes before birth may not be compatible with the very low levels of $\mathrm{C} / \mathrm{EBP} \alpha$ transcripts at birth. However, these observations are from independent studies, the protein determinations are not quantitative, and the concentration of the $\mathrm{C} / \mathrm{EBP} \alpha$ transcript used at translation was not measured.

The pattern of porcine transcript $\mathrm{C} / \mathrm{EPB} \alpha$ gene expression was studied in vitro. In porcine $\mathrm{S} / \mathrm{V}$ cells from day 0 to 7 of cell differentiation, the amount of the $\mathrm{C} / \mathrm{EBP} \alpha$ transcripts was at 40 to $55 \%$ of that on day 10 and doubled between day 7 and 10 of cell differentiation (Ding, 1999). After 1 day of culture in bovine serum plus dexamethasone, $16 \%$ of the $\mathrm{S} / \mathrm{V}$ cells were positive for $\mathrm{C} / \mathrm{EBP} \alpha(\mathrm{Yu}$ and Hausman, 1998). After 3 days of culture, $32 \%$ of the $S / V$ cells were C/EBP $\alpha-$ positive. All cells with lipid deposits were positive for $\mathrm{C} / \mathrm{EBP} \alpha$. In porcine $\mathrm{S} / \mathrm{V}$ cells differentiating in vitro, there was a considerable level of $\mathrm{C} / \mathrm{EBP} \alpha$ present very early in the differentiation as evidenced on $\mathrm{C} / \mathrm{EBP} \alpha$ transcripts and protein levels (Yu and Hausman, 1998). Consistent with these observations was the detection of the $\mathrm{C} / \mathrm{EBP} \alpha$ protein in both porcine $\mathrm{S} / \mathrm{V}$ cells and differentiated adipocytes obtained from 8-day-old pigs (Lee et al., 1998). In contrast, in the rodent-derived clonal cell lines (3T3-L1 and 3T3-F442A), the C/EBP $\alpha$ transcript concentration was undetectable or extremely low in undifferentiated cells and increased rapidly beginning at 3 or 4 days after addition of differentiation medium (Kim and Spiegelman, 1996).

\section{Developmental pattern of fat deposition}

The weight of subcutaneous, ventral and mesentery adipose tissues increased significantly during growth from 1 to $90 \mathrm{~kg}$ body weight $(\mathrm{P}<0.01)$. This result indicated that the capacity of adipose deposition in pigs increased as they grew. 
Wang and Shao (1989) reported that the fat percentage increased significantly as the weight of commercial lean pigs increased. The study from Souza et al. (2004) showed that the fat content of the carcass was significantly correlated $(\mathrm{P}<0.001)$ with animal age; the fat percent in the carcass, shoulder, loin, belly and ham primal cuts significantly increased $(\mathrm{P}<0.05)$ from 16 to 25 weeks of age. The backfat depth at the $\mathrm{P} 2$ site significantly increased $(\mathrm{P}<0.001)$ from 16 to 25 weeks of age. The backfat depth along the carcass midline at the fore, middle and hind sites significantly increased $(\mathrm{P}<0.001)$ in pigs from 16 to 25 weeks of age.

\section{The relation between $C / E P B \alpha$ gene expression and fat deposition}

Several experimental approaches have revealed an adipogenic role for $\mathrm{C} / \mathrm{EBP} \alpha$. This study showed that there was a positive correlation between the levels of $\mathrm{C} / \mathrm{EBP} \alpha$ gene expression and the fat deposition rate. $\mathrm{C} / \mathrm{EBP} \alpha \mathrm{mRNA}$ levels increased as fat was deposited from 1 to $90 \mathrm{~kg}$ liveweight in pigs.

$\mathrm{C} / \mathrm{EBP} \alpha$ regulates the expression of adipocyte-characteristic genes such as lipoprotein lipase (LPL), leptin, adipocyte fatty acid binding protein (aP2), and fatty acid synthase (FAS). The result is adipocyte differentiation, accumulation of triglycerides, and activation of many of the genes involved in adipocyte metabolism. Ultimately, the result is an increase in total white adipose tissue mass (Tontonoz et al., 1994). Disruption of the $\mathrm{C} / \mathrm{EBP} \alpha$ gene gave rise to mice that failed to develop white adipose tissue (Wang et al., 1995).

The $\mathrm{C} / \mathrm{EBP} \alpha$-deficient liver in ob/ob mice had a significantly decreased triglyceride content. Deficiency in hepatic $\mathrm{C} / \mathrm{EBP} \alpha$ expression caused an exacerbation of hyperglycaemia. Hepatic $\mathrm{C} / \mathrm{EBP} \alpha$ plays a critical role in the acceleration of lipogenesis in ob/ob mice and in glucose homeostasis by the indirect regulation of insulin secretion (Matsusue et al., 2004). Recent studies suggest that CCAAT/ enhancing-binding protein (C/EBP) isoforms and sterol regulatory element binding protein (SREBP)-1c regulate fatty acid synthesis in adult type II cells in vitro. Regulation of lipogenesis at the mRNA level is predominantly on enzymes of fatty acid synthesis and appears to be regulated by C/EBP $\alpha$ (Zhang et al., 2004).

\section{CONCLUSIONS}

This study showed the developmental pattern of C/EBP $\alpha$ gene expression in adipose tissue in different growth stages and the positive relation with adipose deposition in pigs.

The characterization of $\mathrm{C} / \mathrm{EBP} \alpha$, a potentially central regulator of adipocyte development, could open the door for novel approaches to regulate fat deposition 
according to the developmental pattern of $\mathrm{C} / \mathrm{EBP} \alpha$ gene expression in pigs and the treatment of obesity and other disorders of adipose tissue in human using specific antagonists of $\mathrm{C} / \mathrm{EBP} \alpha$.

\section{REFERENCES}

Antonson P., Xanthopoulos K.G., 1995. Molecular cloning, sequence, and expression patterns of the human gene encoding CCAAT/enhancer binding protein alpha (C/EBP alpha). Biochem. Biophys. Res. Commun. 215, 106-113

Ding S.-T., McNeel R.L., Mersmann H.J., 1999. Expression of porcine adipocyte transcripts: tissue distribution and differentiation in vitro and in vivo. Comp. Biochem. Physiol. Pt B 123, 307318

Khoo B.Y., Samian M.R., Najimudin N., Tengku Muhammad T.S., 2003. Molecular cloning and characterisation of peroxisome proliferator activated receptor gammal (PPAR $\gamma 1$ ) cDNA gene from guinea pig (Cavia porcellus): determination of tissue distribution of PPAR $\gamma$ in guinea pig. Comp. Biochem. Physiol. Pt B 134, 37-44

Kim J.B., Spiegelman B.M., 1996. ADD1/SREBP1 promotes adipocyte differentiation and gene expression linked to fatty acid metabolism. Gene. Develop. 10, 1096-107

Lee K., Hausman G.J., Dean R.G., 1998. Expression of C/EBPs in fetal and postnatal subcutaneous adipose tissue. Mol. Cell. Biochem. 178, 269-74

Lin F.T., Lane M.D., 1992. Antisense CCAATrenhancer binding protein RNA suppresses coordinate gene expression and triglyceride accumulation during differentiation of 3T3-L1 adipocytes. Gene. Develop. 6, 533-544

MacDougald O.A., Lane M.D., 1995. Transcriptional regulation of gene expression during adipocyte differentiation. Annu. Rev.Biochem. 64, 345-373

Matsusue K., Gavrilova O., Lambert G., Brewer H.B., Ward J.M., Inoue Y., Leroith D., Gonzalez F.J., 2004. Hepatic CCAAT/enhancer binding protein alpha mediates induction of lipogenesis and regulation of glucose homeostasis in leptin-deficient mice. Mol. Endocrinol. 18, 2751-2764

SAS Institute Inc., 1989. SAS User's Guide, Version 6. 4th Edition. Vol 2. Cary, NC

Souza D.N., Pethick D.W., Dunshea F.R., Suster D., Pluske J.R., Mullan B.P., 2004. The pattern of fat and lean muscle tissue deposition differs in the different pork primal cuts of female pigs during the finisher growth phase. Livest. Prod. Sci. 91, 1-8

Tengku Muhammad T.S., Hughes T.R., Ranki H., Cryer A., Ramji D.P., 2000. Differential regulation of macrophage CCAAT-Enhancer binding protein isoforms by lipopolysaccharide and cytokines. Cytokine 12, 1430-1436

Tontonoz P., Hu E., Spiegelman B.M., 1994. Stimulation of adipogenesis in fibroblasts by PPAR gamma 2, a lipid-activated transcription factor. Cell 79, 1147-1156

Umek R.M., Friedman A.D., McKnight S.L., 1991. CCAAT-enhancer binding protein: a component of a differentiation switch. Science 251, 288-292

Vinson C.R., Sigler P.B., McKnight S.L., 1989. Scissors-grip model for DNA recognition by a family of leucine zipper proteins. Science 246, 911-916

Wang B.L., Shao J.B., 1989. The research on the growth developmental law in the commercial lean pigs. Ning xia Agr. Ind. Technol. 10, 34-38

Wang N., Finegold M.J., Bradley A. Ou. C., Abdelsayed S.V., Wilde M.D., Taylor L.R., Wilson D., Darlington G.J., 1995. Impaired energy homeostasis in C/EBP alpha knockout mice. Science $269,1108-1112$ 
Yu Z.K., Hausman G.J., 1998, Expression of CCAAT/enhancer binding proteins during porcine preadipocyte differentiation. Exp. Cell Res. 245, 343-349

Zhang F.J., Pan T.L., Nielsen L.D., Mason R.J., 2004. Lipogenesis in fetal rat lung - Importance of C/EBP alpha SREBP-1c, and stearoyl-CoA desaturase. Amer. J. Respir. Cell Molec. Biol. 30, 174-183 